\title{
Aerobic fungi in the rumen fluid from dairy cattle fed different sources of forage $^{1}$
}

\section{Patrícia Natalicia Mendes de Almeida², Eduardo Robson Duarte ${ }^{3}$, Flávia Oliveira Abrão², Cláudio Eduardo Silva Freitas ${ }^{4}$, Luciana Castro Geraseev ${ }^{3}$, Carlos Augusto Rosa ${ }^{5}$}

\author{
1 Project funded by CAPES, FAPEMIG and CNPq. \\ 2 Programa de Pós-Graduação em Ciências Agrárias - Instituto de Ciências Agrárias da Universidade Federal de Minas Gerais - UFMG. Montes \\ Claros, MG, CEP 39400-401. \\ ${ }^{3}$ Instituto de Ciências Agrárias da Universidade Federal de Minas Gerais, Montes Claros, MG, CEP 39400-401. \\ ${ }^{4}$ Curso de Zootecnia. Instituto de Ciências Agrárias - UFMG, Montes Claros, MG, CEP 39400-401. \\ ${ }^{5}$ Instituto de Ciências Biológicas da Universidade Federal de Minas Gerais - UFMG, Belo Horizonte, MG, CEP 31270-901 - Postal Box 486.
}

\begin{abstract}
The objective of this study was to evaluate the aerobic microbiota of the rumen fluid from Holstein cows and heifers fed different tropical forage in the north of Minas Gerais, Brazil. A total of 30 samples of rumen fluid from cows fed with sorghum silage were collected: 32 from cows fed Brachiaria brizantha, 12 from heifers that received sorghum silage and 11 from calves fed sugar cane foliage. The culture was carried out using the agar Sabouraud medium and the solid $\mathrm{C}$ medium, containing microcrystalline cellulose. The isolated mycelial fungi were identified by microculture technique and yeasts by micromorphological and physical-chemical analysis. Specific identification for yeasts was confirmed by ribosomal DNA sequence analysis. The presence of fungal colonies was confirmed on the Sabouraud medium for $100 \%$ of the samples. No significant differences were observed comparing the concentrations of mycelia fungi in the rumen fluid from cows fed different forages and for the two categories evaluated, fed sorghum silage. Yeast populations in the rumen fluid from heifers fed sugarcane were higher compared with those receiving sorghum silage. The yeast Pichia kudriavzevii (Candida krusei) was the most frequent and among the mycelial fungi, the genus Aspergillus was the most frequently observed, corresponding to $56 \%$ of the samples. Future studies should elucidate the variations in the populations of these microorganisms considering the carbohydrate sources in the tropical forages and the animal categories. The ecological or pathogenic role of these microorganisms should also be considered, aiming at improved productivity and health of cattle.
\end{abstract}

Key Words: dairy farming, forage supplementation, rumen microbiota, semiarid, tropical pasture, yeast

\section{Introduction}

The rumen environment is characterized by a complex mixture of food fragments, water and microorganisms. At this site, there are populations of bacteria, ciliated protozoa, aerobic fungi, mycoplasma and bacteriophage, which establish various positive or negative interactions between themselves (Kamra, 2005; Lopes et al., 2002).

Forages have their growth rate and maturity determined by factors such as water and soil nutrients, temperature and luminosity (Van Soest, 1994), directly influencing the diet quality and the levels of volatile fatty acids (VFA) and ammonia $\left(\mathrm{NH}_{3}\right)$ available in the rumen. These nutrients can directly influence the populations of bacteria and fungi in the rumen (Dehority, 1998). The establishment and maintenance of the balance of the microbial populations is dependent on the quality of the diet, the feed distribution frequency, as well as microbial interactions occurring in the rumen (Dehority, 1998; Martillotti et al., 1994).
The natural occurrence of aerobic fungi in the rumen has seldom been described in the literature. However, there are reports of the biotechnological potential of these microorganisms for various purposes such as production of enzymes (Pinto et al., 2001), antibiotics, vitamins, pharmaceutical compounds, hormonesand proteins (Kavanagh, 2005). The addition of the extract from Aspergillus oryzae, fungus used in the production of soy sauce, increased by three times the zoospores of Neocallimastix frontalis, cellulolytic fungus from the rumen of dairy cows. This result indicated the promising potential of adding extract of $A$. oryzae in the rumen environment (Schmidt et al., 2004). A live microbial environment of exogenous fungi A. orizae and Sacchariomyces cerevisae has been used as nutritional supplements in diets for animals, improving the productivity of ruminants in up to $8 \%$ (Martin \& Nisbet, 1992; Wallace, 1994). On the other hand, fungi may sporadically cause infections in animals, humans and plants, and these lesions are frequently associated with predisposing factors (Casadevall, 2007). 
The objective of this research was to quantify and identify aerobic fungi in the rumen fluid from different categories of dairy cattle fed different sources of tropical forages.

\section{Material and Methods}

The collection of rumen fluid samples was performed at the Fazenda Experimental do Instituto de Ciências Agrárias (ICA), owned by Universidade Federal de Minas Gerais (UFMG) and another farm located in the municipality of Montes Claros, which is located in the northern part of the state of Minas Gerais, Brazil. The geographic coordinates of this region correspond to south latitude $16^{\circ} 50^{\prime} 52^{\prime \prime}$, west longitude $43^{\circ} 55^{\prime} 29^{\prime \prime}$ and it is at an altitude of $646 \mathrm{~m}$ above the sea level. The climate classification by Köppen-Geiger is of the Aw type, considered a tropical savanna, with a long dry period (April-October) and a short rainy season (November-March). The average temperature during the period in which this experiment was conducted, from November 2008 to August 2009, was of $22.9^{\circ} \mathrm{C}$ and the rainfall was of $960.0 \mathrm{~mm}$, according to the $5^{\circ}$ Distrito do Instituto Nacional de Meteorologia, located in Montes Claros.

Four treatments were evaluated in a completely randomized design, considering the use of different forages by different categories of animals. Samples were collected from the rumen contents of cows and calves with a predominant degree of the Holstein breed.

The cows and calves were on average 5.91 and 1.08 years old and had an average weight of 546 and $196.8 \mathrm{~kg}$, respectively. All were partially confined and received supplementation in a concrete trough.

In all the treatments, except for the animals on pasture, the animals were fed at $8 \mathrm{~h} 00$ and again at $16 \mathrm{~h} 00$. The treatments were compared two by two in order to evaluate the effect of the diet or the animal age on the rumen aerobic mycobiota.
Samples were collected from 30 cows fed sorghum silage. These animals received a daily average of $35 \mathrm{~kg}$ of sorghum silage (Table 1) per animal as the sole source of forage, and $5 \mathrm{~kg}$ animal ${ }^{-1}$ of concentrate. This concentrate had ground corn grain $\left(700 \mathrm{~g} \mathrm{~kg}^{-1}\right)$, soybean $\left(250 \mathrm{~g} \mathrm{~kg}^{-1}\right)$, urea $\left(20 \mathrm{~g} \mathrm{~kg}^{-1}\right)$ and mineral premix $\left(30 \mathrm{~g} \mathrm{~kg}^{-1}\right)$. The animals also had available, in a concrete trough, the premix and mineral salt at a $1: 1$ ratio.

The second group of 30 cows was fed exclusively Brachiaria brizantha during the summer period, from January to April 2009. Animals also received the same mixture of common salt and mineral premix as animals of the previous group ad libitum.

After a period of 60 days consuming sorghum silage, 12 heifers were subjected to collection of rumen fluid. These animals consumed a daily average of $15 \mathrm{~kg}_{\text {animal }}{ }^{-1}$ of the same the silage provided to the cows and $2 \mathrm{~kg}$ of concentrate (Table 1). The ingredients used in the concentrate were crushed sorghum (700 $\left.\mathrm{g} \mathrm{kg}^{-1}\right)$, soybean meal (250 $\left.\mathrm{g} \mathrm{kg}^{-1}\right)$, urea $\left(20 \mathrm{~g} \mathrm{~kg}^{-1}\right)$ and mineral premix $\left(30 \mathrm{~g} \mathrm{~kg}^{-1}\right)$. The calves also had a mixture of premix mineral and mineral salt at 1.5:1 ratio ad libitum, and were maintained in a threehectare paddock area.

The calves used in this treatment were adapted to the diet with chopped sugarcane forage (Table 1) for a period of 43 days, reaching an average daily intake of $9.2 \mathrm{~kg}^{\text {animal }}{ }^{-1}$. Before the feed supply, urea and ammonium sulfate were added at 9:1, both diluted in water. The amount of urea and ammonium sulfate mixture was supplied at $40 \mathrm{~g} 100 \mathrm{~kg}^{-1}$ of animal body weight. The mixture of mineral premix and salt previously reported was also provided ad libitum.

In the morning, the animals were immobilized in a containment chute before the first meal. For the collection of rumen fluid, a trichotomy and a antisepsis with PVPiodine solution $(1 \%)$ were performed in an area of approximately $5 \mathrm{~cm}^{2}$ located in the left ventral abdomen, below the paralumbar fosse and cranial to the knee joint

Table 1 - Chemical composition of sorghum silage, Brachiaria brizantha grass, chopped sugarcane and the concentrate fed to the cows and heifers

\begin{tabular}{|c|c|c|c|c|c|}
\hline Parameters & Sorghum silage & $\begin{array}{c}\text { Brachiaria } \\
\text { brizantha }\end{array}$ & $\begin{array}{c}\text { Chopped } \\
\text { sugarcane* }\end{array}$ & $\begin{array}{c}\text { Concentrate } \\
\text { to cows }\end{array}$ & $\begin{array}{c}\text { Concentrate to } \\
\text { calves }\end{array}$ \\
\hline Dry matter (DM), $\mathrm{g} \mathrm{kg}^{-1}$ of natural matter & 310.4 & 327.6 & 248.4 & 853.6 & 865.0 \\
\hline Neutral detergent fiber, $\mathrm{g} \mathrm{kg}^{-1} \mathrm{DM}$ & 462.8 & 374.9 & 366.8 & 105.6 & 181.2 \\
\hline Crude protein, $\mathrm{g} \mathrm{kg}^{-1} \mathrm{DM}$ & 54.5 & 60.2 & 51.6 & 186.5 & 116.1 \\
\hline Ether extract, $\mathrm{g} \mathrm{kg}^{-1} \mathrm{DM}$ & 29.3 & 20.2 & 9.0 & 51.5 & 47.1 \\
\hline Mineral matter (ash), $\mathrm{g} \mathrm{kg}^{-1} \mathrm{DM}$ & 74.4 & 66.1 & 73.7 & 82.7 & 43.9 \\
\hline
\end{tabular}

* Without the addition of urea and ammonium sulfate.

$\mathrm{TC}=100-(\mathrm{CP}+\mathrm{EE}+\mathrm{MM})$ and $\mathrm{NFC}=\mathrm{TC}-\mathrm{NDF}$, according to Weiss $(1998)$. 
(Dirksen, 1993). With the aid of human catheter (Solidor ${ }^{\circledR}$, 14.2, BioMed Health Care Products, Haryana - India) coupled to sterile syringes, $15 \mathrm{~mL}$ of rumen fluid were aspirated. Each syringe was sealed, identified, stored in isothermal box containing ice and sent to the laboratory.

Cultivation was performed in triplicate to assess the positivity of mycelial fungi and yeast for all animals evaluated. Sterile swabs were used to inoculate rumen fluid in Petri plates containing Sabouraud agar medium (Acumedia ${ }^{\circledR}$ Manufactures, Lansing, Michigan - USA), supplemented; with chloramphenicol (150 mg mL $\left.\mathrm{mL}^{-1}\right)$ and in plates with medium $\mathrm{C}$ (10 $\mathrm{g}$ of microcrystalline cellulose; $5 \mathrm{~g}$ of ammonium sulfate; $0.5 \mathrm{~g}$ of magnesium sulfate heptahydrate; and $20 \mathrm{~g}$ of agar-agar per liter. After inoculation by striation, samples were cultured in BOD incubate at $39{ }^{\circ} \mathrm{C}$ and monitored for the growth of fungal colonies during 21 days (Lacaz et al., 2002).

Decimal dilutions of the rumen fluid were prepared in tubes containing $9 \mathrm{~mL}$ of sterile saline. The tubes were then homogenized in a vortex for one minute and $100 \mu \mathrm{L}$ aliquots of the decimal dilutions were seeded in sterile plates containing the Sabouraud agar medium, as described above. The inoculates were spread evenly with sterile Drigalski handles; the plates were then incubated in an BOD chamber at $39{ }^{\circ} \mathrm{C}$ and monitored for growth of fungal colonies for up to 21 days (Kurtzman \& Fell, 1998; Lacaz et al., 2002).

For the identification of the mycelial fungi isolates, microculture exams were performed according to the technique of Riddell (Lacaz et al., 1998). The micromorphological characteristics, as demonstrated by optical microscope, were linked to those described for fungi of biotechnological and veterinary interest (Lacaz et al., 2002).

The yeast isolates from samples of rumen fluid from cows and heifers fed sorghum silage were previously stained with the Gram technique and grouped according to the physiological, biochemical and micromorphological profiles (Kurtzman \& Fell, 1998). Biochemical and physiological characterization considered the capacity of fermentation and the assimilation of carbon and nitrogen sources (glucose, galactose, L-sorbose, maltose, sucrose, cellobiose, trehalose, lactose, melibiose, raffinose, melezitose, inulin, soluble starch, D-xylose, L-arabinose, D-arabinose, D-ribose, L-rhamnose, ethanol, glycerol, erythritol, adonitol, galactitol, D-mannitol, D-glucitol, salicin, DL-lactate, succinate, citrate, m-inositol, methanol, hexadecane, xylitol, gluconate, isopropanol, ethylacetate, acetone, $\mathrm{N}$-acetylglucosamine, glucosamine, lysine carbonate, nitrite, nitrate and resistance $\mathrm{NaCl}$, acetic acid and cyclohexamide according to the procedures described in Kurtzman \& Fell (1998).

After grouping these yeasts, molecular analysis of the sequences of domains D1 and D2 of the largest subunit of DNAr amplified by polymerase chain reaction (PCR) were proceeded. The primers used were NL1 (5'-GCA TAT CAA AAG GAA GAG TAA GCC-3') and NL4 (5'-GGT AAG CTT GCA TGT CCG G-3'). PCR reactions were performed in PCR Express thermocycler (Thermo Hybaid). The cycling program used the initial denaturation at $95^{\circ} \mathrm{C}$ for 5 minutes followed by 35 cycles of 15 seconds of denaturation at $94{ }^{\circ} \mathrm{C}, 25$ seconds annealing of the primer at $54{ }^{\circ} \mathrm{C}$ and 20 -second extension at $68{ }^{\circ} \mathrm{C}$ and a final extension for 10 minutes at $68{ }^{\circ} \mathrm{C}$. For the PCR products, $1.5 \mathrm{~mL}$ of Gel Red solution were added for analysis by electrophoresis on $1 \%$ agarose gel in $0.5 \mathrm{X}$ TBE buffer. The gels were visualized under ultraviolet light. The amplicons produced were purified and measured in a NanoDrop ND 1000 (NanoDrop Technologies). The sequencing reactions were performed in a DYEnamicTM (Amersham Biosciences, USA) associated with the automated sequencing system MegaBACETM 1000 (Lachance et al., 1999).

The sequences of the rDNA fragments were analyzed in the software BLASTN (Basic Local Alignment Search Tool - 2215 BLAST, version 2.0) available on the website of the National Center for Biotechnology 1 (Altschul et al., 1997). Isolates with similarity equal or superior to $99 \%$ to another previously deposited were considered to belong to the species indicated.

After exploratory data analysis for quantification of fungi with the Lilliefors and Bartlett tests, proceeded to the transformation of the cfu data in $\log _{10}(\mathrm{X}+10)$. As the variables did not present a normal distribution, the Wilcoxon nonparametric test was adopted to compare means between treatments, which were analyzed in pairs (T1 to T2, T1 to $\mathrm{T} 3$, and $\mathrm{T} 3$ to $\mathrm{T} 4)$. The positivity and distribution rates of the fungi genera for different groups of animals were evaluated using the Chi-square $\left(\chi^{2}\right)$ (Sampaio, 1998). These analyses were performed on statistical package $\mathrm{SAEG}^{\circledR}$ (Sistema para Análises Estatísticas e Genéticas, 9.1 version), considering significant differences with $\mathrm{P}<0.05$.

\section{Results}

The culture in the Sabouraud agar medium and the C medium indicated the presence of fungi for all groups of animals evaluated. However, the positivity rate of fungi in the $\mathrm{C}$ medium for cows fed on pasture was significantly lower $(86.7 \%)$ when compared with rates observed for cows fed sorghhum silage (100\%).

R. Bras. Zootec., v.41, n.11, p.2336-2342, 2012 
For cows fed sorghum silage or pasture, the population of mycelial fungi in the rumen did not change significantly. However, for cows fed silage, a higher population of yeasts was observed and the mycelial fungi/yeast ratio was lower $(\mathrm{P}<0.05)$ (Table 2).

The population of mycelial fungi and the mycelial fungi/yeast ratio was significantly lower for calves fed chopped sugar cane. However, in this treatment, the average cfu of yeasts was higher $(\mathrm{P}<0.05)$ when compared with the population observed in calves fed the silage (Table 2).

Comparing the population of fungi between the categories of cows and heifers fed sorghum silage, it was observed that the population of filamentous fungi did not differ between cows and heifers $(\mathrm{P}>0.05)$. Moreover, for the calves, the average cfu of yeast was greater, and the mycelial fungi/yeast ratio was lower in the rumen $(\mathrm{P}<0.05)$ (Table 2). These results indicate major changes in the populations of yeasts and the relationship between these two groups of microorganisms, either caused by the diet offered or the category evaluated.

A total of 105 strains of mycelial fungi from samples of rumen fluid were identified.

It was observed that the genus Aspergillus was the most frequent and predominated among isolates from T1, T2 and $\mathrm{T} 3(\mathrm{P}<0.01)$. Among the isolates of the genus Rhizophus,

Table 2 - Statistical comparisons and average quantification of mycelial and yeast fungi in samples of rumen fluid from cows fed sorghum silage $(\mathrm{n}=32)$, cows fed on pasture of Brachiaria brizantha $(\mathrm{n}=30)$, heifers fed sorghum silage $(n=12)$ or sugarcane $(n=11)$

\begin{tabular}{lccc}
\hline Treatment & $\begin{array}{c}\text { Mycelial fungi } \\
(\mathrm{cfu} / \mathrm{mL})\end{array}$ & $\begin{array}{c}\text { Yeasts } \\
(\mathrm{cfu} / \mathrm{mL})\end{array}$ & $\begin{array}{c}\text { Mycelial/yeast } \\
\text { fungi ratio }\end{array}$ \\
\hline Cows silage (T1) & $8.8 \times 10^{5} \mathrm{~A}$ & $1.6 \times 10^{5} \mathrm{~A}$ & $6.0 \times 10^{1} \mathrm{~B}$ \\
Cows grass (T2) & $2.1 \times 10^{5} \mathrm{~A}$ & $3.5 \times 10^{3} \mathrm{~B}$ & $1.8 \times 10^{5} \mathrm{~A}$ \\
Calves silage (T3) & $1.6 \times 10^{5} \mathrm{~A}$ & $2.0 \times 10^{6} \mathrm{~B}$ & $3.0 \times 10^{-1} \mathrm{~A}$ \\
Calves cane (T4) & $3.6 \times 10^{4} \mathrm{~B}$ & $5.0 \times 10^{6} \mathrm{~A}$ & $8.5 \times 10^{-3} \mathrm{~B}$ \\
Cows silage (T1) & $8.8 \times 10^{5} \mathrm{~A}$ & $1.6 \times 10^{5} \mathrm{~B}$ & $6.0 \times 10^{1} \mathrm{~A}$ \\
Calves silage (T3) & $1.6 \times 10^{5} \mathrm{~A}$ & $2.0 \times 10^{6} \mathrm{~A}$ & $3.0 \times 10^{-1} \mathrm{~B}$ \\
\hline
\end{tabular}

the incidence was significantly higher for calves fed silage (27\%) compared with animals fed sugarcane (Table 3).

A total of 38 yeast isolates were selected and subjected to identification by biochemical and physiological tests and analysis of rDNA sequences (Figure 1). This analysis indicated that 32 isolates corresponded to the species Pichia kudriavzevii (Candida krusei), four to the species Candida glabrata and two were identified as Candida pararugosa.

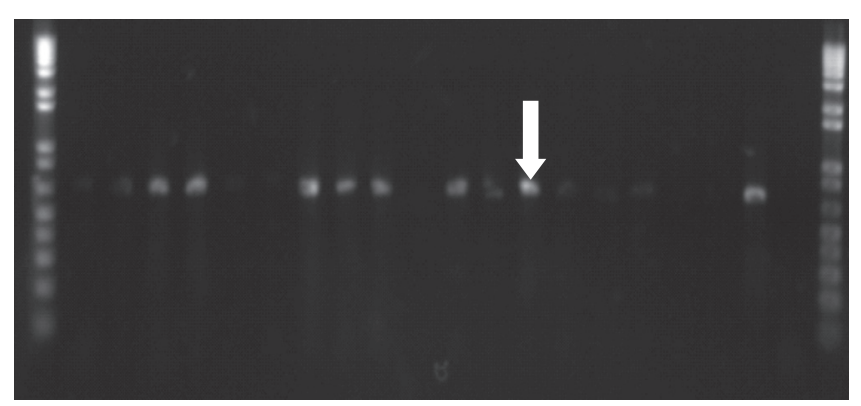

The arrow indicates amplification of $600 \mathrm{pb}$ DNAr fragment of the rumen yeast, quantified NanoDrop ND $1000 \mathrm{bp}$.

Figure 1 - Agarose gel electrophoresis of DNAr fragments amplified with primers NL1 and NL4.

\section{Discussion}

The high positivity rate and high average of $\mathrm{cfu} \mathrm{mL}^{-1}$ for mycelial fungi (1.6 to $\left.8.8 \times 10^{5}\right)$, observed for those animals fed sorghum silage, could suggest that this feed had been a source of contamination of these microorganisms in the rumen. This could be supported by studies that describe the presence of these fungi in sorghum and maize silages (Mngadi et al., 2008; O’Brien et al., 2007; Richard et al., 2009).

Moreover, there was a greater yeast population for heifers fed chopped sugarcane compared with those fed the silage (Table 2). The predominance could possibly be related to the type of carbohydrate available. Yeasts are

Table 3 - Mycelial fungi genus distribution from the rumen fluid samples for each experimental group in this study

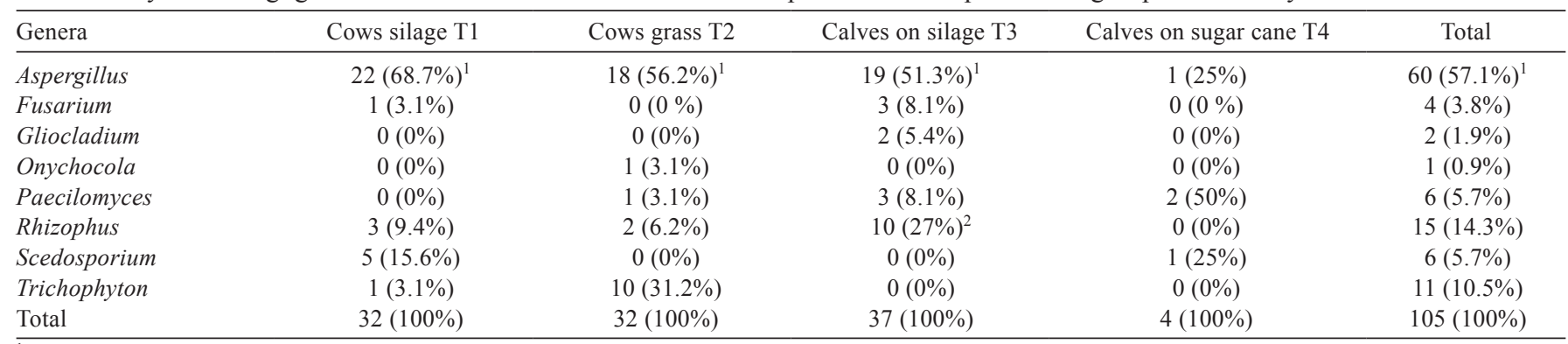

${ }^{1}$ Increased frequency between isolates compared in the column $(\mathrm{P}<0.01)$.

${ }^{2}$ Higher occurrence when compared between heifers fed with sorghum silage and sugarcane $(\mathrm{P}<0.05)$. 
better able to degrade simple carbohydrates (Kurtzman \& Fell, 1998), while the mycelial fungi produce a large quantity and variety of enzymes to degrade the polysaccharide cell wall of plants (McAllister et al., 2001; Ximenes, 2003). Thus, diets rich in soluble carbohydrates, as is the sucrose present in the sugarcane forage, could have competitively favored the growth of the yeast population. There still could have been antagonistic substances produced by yeast, inhibiting the growth of mycelial fungi (Coelho et al., 2007), which should be evaluated and considered in future research.

Considering the age factor, the higher number of $\mathrm{cfu} / \mathrm{mL}$ of yeast in the rumen of calves compared with cows, both fed sorghum silage, could be justified by the greater instability of the rumen environment of young animals (Ruiz-Lacaz et al., 1992; Dirksen, 1993).

In the analysis and identification of mycelial isolates (Table 3), the genus Aspergillus was the most frequent $(\mathrm{P}<0.01)$. The predominance of this genus could be justified by its versatility and efficiency to catabolize carbon sources and also soluble polymer complexes (Flipphi et al., 2009). This capacity can be proven in a study with the addition of live cultures of Aspergillus oryzae or Sacchariomyces cerevisiae and its extracts used as supplements in the diet of ruminants. These microbial additives can increase the productivity by about 7 to $8 \%$ (Wallace, 1994), improving weight gain, digestibility of total fiber (Tricarico et al., 2008) and promoting positive changes in the rumen digestion of starch (Di Francia et al., 2008). However, the addition of strains of Aspergillus spp. in the diet should be done with caution, since this genus is one of the most important mycotoxin-producing agents in the food for animals and humans (Hirsch et al., 2003; Kamei \& Watanabe, 2005; Prange et al., 2005).

Among the isolates of the genus Rhizophus, the incidence was significantly higher for calves fed silage (27\%) compared with that observed for animals fed sugarcane. This result suggests the sorghum silage as a possible source of contamination of this and other fungi, as previously reported in scientific literature (Mngadi et al., 2008; O'Brien et al., 2007; Richard et al., 2009). A lower proportion of this genus for the cows fed sorghum silage $(\mathrm{P}<0.05)$ was also observed, compared with calves supplemented with the same diet (Table 3), and these differences could be attributed to the instability observed in the rumen of young animals (Ruiz-Lacaz et al., 1992).

The genus Trichophyton, considered typical pathogen and agent of dermatomycoses in humans and animals (Lacaz et al., 2002), was more frequent for samples of rumen fluid from cows fed on pasture. Specifically for this dermatophyte, the occurrence and participation in the rumen has not been reported in scientific literature; however, the source of its inoculation could be attributed to the licking of the skin and hair, considered common sites for some species of this genus. These fungi have a remarkable ability to use keratin (Lacaz et al., 2002), which is also on the skin and in the rumen mucosa. The Thichophyton mentagrophytes species secretes urease (Lacaz et al., 2002), which could suggest their involvement in the use of urea supplied to the animals.

The genera Trichophyton, Aspergillus and Fusarium are widely studied for their implications in public health, in dermatomycoses, or as producing agents of mycotoxins (Lacaz et al., 2002). Occasionally, fungi of the genera Acremonium, Scedosporium and Onychocola are referred to as pathological. Although they are often found in this environment, these fungi can infect immunocompromised human patients (Barreto-Bergter et al., 2008; Bienvenu et al., 2009; Guarro et al., 2009).

The genus Aspergillus may have direct implications on the health of the ruminants, when associated with severe fungal ruminitis (Jensen et al., 1994). Chihaya et al. (1992) reported mycotic ruminitis in 38 of 692 cattle older than six months. At necropsy, focal hemorrhagic necrosis was observed in the rumen wall with thrombosis and the presence of hyphae typical of Mucor spp. and Aspergillus spp, proving the presence of these agents.

For the genus Paecilomyces, tests demonstrated ovicidal efficacy of $52 \%$ of P. lilacinus on Taenia saginata eggs, after ten days of cultivation (Braga et al., 2008). This data indicates the importance of assessing the biotechnological potential of microorganisms isolated in this study, be it for the control of agents of diseases or additives in ruminant nutrition. However, the pathogenic and toxicological role should also be considered for both animal and human health.

Specific identification of yeasts was made possible by the use of PCR and sequencing of ribosomal DNA(Figures 1 and 2). The biochemical and physiological characterization detect that the samples of Pichia kudriavzevii (C. krusei) grew at a faster rate between 37 and $40{ }^{\circ} \mathrm{C}$ and standard fermentation using glucose, D-xylose, DL-lactate, succinate, acetone, ethyl acetate, isopropanol, $\mathrm{N}$-acetylglucosamine, lysine and carbonate increased concentration in the $10 \%$ $\mathrm{NaCl}$. Some strains also grew in the medium without any amino acid. According to this data, one can infer that this species uses lactate and this could also contribute to the regulation of rumen $\mathrm{pH}$.

The species C. glabrata and C. pararugos identified in this study are important opportunist agents and can 
cause systemic mycoses in immunocompromised humans (Bodey et al., 2002). In addition, these yeasts often showed a population with multiple resistance to antifungal drugs (Samaranayake \& Samaranayake, 1994). The genus Candida and other yeasts may be associated with cases of clinical or subclinical mastitis in ruminants, either as primary or secondary agents (Spanamberg et al., 2009). There are also reports that Candida glabrata can be intrinsically associated with diarrhea in newborn calves (Elad et al., 1998; Radostitis et al., 2000).

Lund (1974) isolated C. krusei (P. kudriavzevii) of 49 samples of rumen fluid from healthy dairy cows, corresponding to the most frequently identified specie. This result is consistent with findings in this research and suggests the participation of this species in the mycobiota of the bovine rumen. However, Abrão et al. (2011) isolated 30 yeasts in the rumen of goats raised in tropical pastures in the north of Minas Gerais and $90 \%$ of the isolates corresponded to the species Pichia membranifaciens and $10 \%$ to Candida tropicalis. Comparing with the results obtained in this study, it is suggested that the occurrence of those yeast species may change according to ruminant species, which should be considered in future studies.

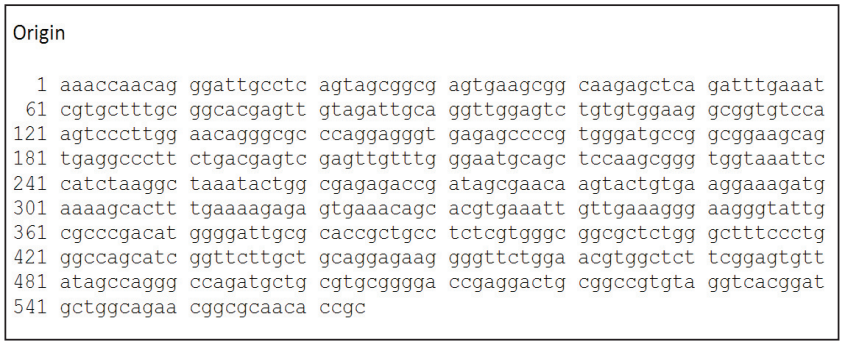

Figure 2 - Sequence of 1-564 nucleotides of the domains D1 D2 of $26 \mathrm{~S}$ rDNA, amplified with primers NL1 and NL2 for samples identified as Pichia kudriavzevii (Candida krusei) from the rumen of cows.

\section{Conclusions}

Aspergillus spp. and Pichia kudriavzevii fungi are predominant among isolates from the rumen of dairy cattle fed tropical forages, with differences in the concentrations of colony-forming units in function of the forage offered and the animal category.

\section{Acknowledgements}

This study was supported by Conselho Nacional de Desenvolvimento Científico e Tecnológico (CNPq),
Fundação de Amparo à Pesquisa do Estado de Minas Gerais (FAPEMIG) and Pró-Reitoria de pesquisa of Universidade Federal de Minas Gerais.

\section{References}

ABRÃO, F.O.; FREITAS, C.E.S.; DUARTE, E.R. et al. Leveduras no rúmen de caprinos e bovinos de corte criados em pastagem tropicais. Arquivo Brasileiro de Medicina Veterinária e Zootecnia, v.63, p.526-529, 2011.

ALTSCHUL, S.F.; MADDEN, T. L.; SCHAFFER, A.A. et al. Gapped BLAST nad PSI-BLAST: a new generation of protein database search programs. Nucleic Acids Research, v.25, p.3389-3402, 1997.

BARRETO-BERGTER, E.; SASSAKI, G.L.; WAGNER, R. et al. The opportunistic fungal pathogen Scedosporium prolificans: carbohydrate epitopes of its glycoproteins. International Journal of Biological Macromolecules, v.42, p.93-102, 2008.

BIENVENU, A.L.; RIGOLLET, L.; MARTINS-CARVALHO, C. et al. Un cas d'otite externe compliquee d'une osteolyse due a Scedosporium apiospermum. Journal of Medical Mycology, v.19, p.129-133, 2009.

BODEY, G.P.; MARDANI, M.; HANNA, H.A. et al. The epidemiology of Candida glabrata and Candida albicans fungemia in immunocompromised patients with cancer. American Journal of Medicine, v.112, p.380-385, 2002.

BRAGA, F.R.; ARAÚJO, J.V.; ARAUJO, J.M. et al. Efeito do fungo Paecilomyces lilacinus sobre ovos de Taenia saginata. Revista da Sociedade Brasileira de Medicina Tropical, v.41, p.686-688, 2008.

CASADEVALL, A. Determinants of virulence in the pathogenic fungi. Fungal Biology Reviews, v.21, p.130-132, 2007.

CHIHAYA, Y.; MATSUKAWA, K.; OHSHIMA, K. et al. A pathological study of bovine alimentary mycosis. Journal of Comparative Pathology, v.107, n.2, p.195-206, 1992.

COElHO, A.R.; CELli, M.G.; ONO, E.Y.S. et al. Penicillium expansum versus antagonist yeasts and patulin degradation in vitro. Brazilian Archives Biology Technology, v.50, n.4, p.725-733, 2007.

DEHORITY, B.A. Microbial interactions in the rumen. Revista de La Facultad de Agronomía Luz, v.15, p.69-86, 1998.

DI FRANCIA, A.; MASUCCI, F.; DE ROSA, G. et al. Effects of Aspergillus oryzae extract and a Saccharomyces cerevisiae fermentation product on intake, body weight gain and digestibility in buffalo calves. Animal Feed Science and Technology, v.140, p.67-77, 2008.

DIRKSEN, G. Sistema digestivo. In: DIRKSEN, G.; GRÜNDER, H.D.; STÖBER, M. (Ed.). Rosenberger: exame clínico dos bovinos. Rio de Janeiro: Guanabara Koogan. 1993. p.167-169.

ELAD, D.; BRENNER, J.; MARKOVICS A. et al. Yeasts in the gastrointestinal tract of preweaned calves and possible involvement of Candida glabrata in neonatal calf diarrhea. Mycopathologia, v.141, p.7-14, 1998

FLIPPHI, M.; SUN, J.; ROBELLET, X. et al. Biodiversity and evolution of primary carbon metabolism in Aspergillus nidulans and other Aspergillus spp. Fungal Genetics and Biology, v.46, p.19-44, 2009.

GUARRO, J.; DEL PALACIO, A.; GENÉ, J. et al. A case of colonization of a prosthetic mitral valve by Acremonium strictum. Revista Iberoamericana de Micologia, v.26, p.146-148, 2009.

HIRSH, D.C.; ZEE, Y.C; COUTINHO, A.S. et al. Microbiologia veterinária. Rio de Janeiro: Guanabara Koogan, 2003. 446p.

JENSEN, H.E.; OLSEN, S.N.; AALBEK, B. Gastrointestinal Aspergillosis and Zygomycosis of Cattle, Veterinary Pathology, v.31, p.28-36, 1994

KAMEI, K.; WATANABE, A. Aspergillus mycotoxins and their effect on the host. Medical Mycology, v.43, p.95-99, 2005. 
KAMRA, D.N. Rumen microbial ecosystem. Current Science, v.89, p.125-135, 2005.

KAVANAGH, K. Fungi: Biology and applications. London, UK: Wiley Press, 2005. 280p.

KURTZMAN, C.P.; FELL, J.W. The yeasts: a taxonomic study. 4.ed. Amsterdam: Elsevier, 1998. 1055p.

LACAZ, C.S.; PORTO, E.; HEINS-VACCARI, E.M. et al. Guia para identificação de fungos actinomicetos e algas de interesse médico. 8.ed. São Paulo: Sarvier, 1998. 320p.

LACAZ, C.S.; MELO, N.T.; HEINS-VACCARI, E.M. et al. Tratado de micologia médica Lacaz. 9.ed. São Paulo: Sarvier, 2002. 1104p.

LACHANCE, M.A.; BOWLES, J.M.; STARMER, W.T. et al. Kodamacea kakaduensis and Candida tolerans, two new ascomycetous yeast species from Australian Hibiscus flowers. Canadian Journal of Microbiology, v.45, p.172-177, 1999.

LOPES, F.C.F.; AROEIRA, L.J.M.; ARCURI, P.B. et al. Efeitos da defaunação em ovinos alimentados com cana-de-açúcar (Saccharum officinarum, L.) adicionada de uréia. Arquivo Brasileiro de Medicina Veterinária e Zootecnia, v.54, p.180-182, 2002.

LUND, A. Yeasts and moulds in the bovine rumen. Journal of General Microbiology, v.81, p.453-462, 1974.

MARTILLOTTI, F.; TERRAMOCCIA, S.; TRIPALDI, C. et al. Microbial and chemical characterization of rumen contents of grazing dairy cows. In: PRINS, R.A.; STEWART, C.S.(Eds.). Micro-organisms in ruminant nutrition. Dalfsen: Nottingham University Press, 1994. p.43-48.

MARTIN, A.S.; NISBET, D.J. Effect of direct-feed microbial on rumen microbial fermentation. Journal of Dairy Science, v.75, p.1736-1744, 1992.

MCALLISTER, T.A.; HRISTOV, A.N.; BEAUCHEMIN, K.A. et al. Enzymes in ruminant diets. In: BEDFORD, M.R.; PARTRIDGE, G.G. (Eds.) Enzymes in farm animal nutrition. Oxon: Cab International, 2001. p.273-298.

MNGADI, P.T.; GOVINDEN, R.; ODHAV, B. Co-occurring mycotoxins in animal feeds. African Journal of Biotechnology, v.7, p.2239-2243, 2008.

O'BRIEN, M.; O'KIELY, P.; FORRISTAL P.D. et al. Visible fungal growth on baled grass silage during the winter feeding season in Ireland and silage characteristics associated with the occurrence of fungi. Animal Feed Science and Technology, v.139, p.234-256, 2007.
PINTO, G.A.S.; LEITE, S.G.F.; TERZI, S.C. et al. Selection of tannase-producing Aspergillus niger Strains. Brazilian Journal of Microbiology, v.32, p.24-26, 2001.

PRANGE, A.; MODROW, H.; HORMES, J. et al. Influence of mycotoxin producing Fungi (Fusarium, Aspergillus, Penicillium) on gluten proteins during suboptimal storage of wheat after harvest and competitive interactions between field and storage fungi. Journal of Agricultural and Food Chemistry, v.53, p.6930-6938, 2005.

RADOSTITIS, E.M.; GAY, C.C.; BLOOD, D.C. et al. Veterinary medicine. 9.ed. London: W.B.Saunders, 2000. 1881p.

RICHARD, E.; HEUTTE, N.; BOUCHART, V. et al. Evaluation of fungal contamination and mycotoxin production in maize silage animal feed. Science and Technology, v.148, p.309-320, 2009.

RUIZ-LACAZ, R. Microbiologia zootécnica. São Paulo: Roca, 1992. p.123-167.

SAMARANAYAKE, Y.H.; SAMARANAYAKE, L.P. Candida krusei: biology, epidemiology, pathogenicity and clinical manifestations of an emerging pathogen. Journal of Medical Microbiology, v.41, p.295-310, 1994.

SAMPAIO, I.B.M. Estatística aplicada à experimentação animal. Belo Horizonte: Fundação de Ensino e Pesquisa em Medicina Veterinária e Zootecnia. 1998. 221p.

SCHMIDT, J.A.; ALBRIGHT, S.; TSAI, K.P. et al. Characterization of Aspergillus oryzae fermentation extract effects on the rumen fungus Neocallimastix frontalis, EB 188. Applied Microbiology Biotechnology, v.63, p.422-430, 2004.

SPANAMBERG, A.; SANCHES, E.M.C.; SANTURIO, J.M. et al. Mastite micótica em ruminantes causada por leveduras. Ciência Rural, v.39, p.282-290, 2009.

TRICARICO, J.M.; JOHNSTON, J.D.; DAWSON, K.A. Dietary supplementation of ruminant diets with an Aspergillus oryzae $\alpha-$ amylase Animal Feed Science and Technology, v.145, p.136-150, 2008.

VAN SOEST, P.J. Nutritional ecology of the ruminant. 2.ed. Ithaca: Cornell University Press, 1994. 476p.

WALLACE, R.J. Rumen microbiology, biotechnology, and ruminant nutrition: progress and problems. Journal Animal Science, v.72, p.2992-3003, 1994.

WEISS, W.P. Estimating the available energy content of feeds for dairy cattle. In: Symposium: energy availability. Journal of Dairy Science, v.81, p.830-839, 1998.

XIMENES, E. Fungos Anaeróbios. Revista de Ciências Médicas e Biológicas, v.2, p.269-275, 2003. 